\title{
The Miracles of Surfactant: Less Invasive Surfactant Administration, Nebulization, and Carrier of Topical Drugs
}

\author{
Christoph Härtel $^{\mathrm{a}} \quad$ Kirsten Glaser $^{\mathrm{b}} \quad$ Christian P. Speer $^{\mathrm{a}}$

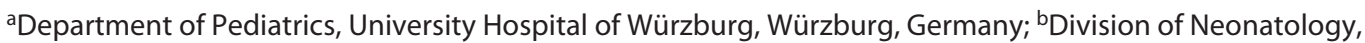 \\ Department of Women's and Children's Health, University of Leipzig Medical Center, Leipzig, Germany
}

\section{Keywords}

Surfactant $\cdot$ Respiratory distress syndrome $\cdot$ Less invasive surfactant administration - Nebulization - Carrier of topical drugs

\begin{abstract}
Surfactant replacement therapy (SRT) has long become the standard of care in the treatment of neonatal respiratory distress syndrome (RDS), significantly decreasing acute pulmonary morbidity and mortality in preterm infants. For decades, this beneficial replacement therapy has been administered via endotracheal tube. Despite significantly improving the outcome of RDS, however, the burden of bronchopulmonary dysplasia remains, in particular, in very immature preterm infants. Acknowledging the direct relationship between exposure to and duration of invasive mechanical ventilation and chronic lung disease, the latter has been gradually replaced by noninvasive ventilation strategies in neonatal RDS. This replacement is strongly related to the demand for similarly noninvasive modes of surfactant administration. Alternative techniques in spontaneously breathing infants have evolved, including less invasive techniques using thin catheters (less invasive surfactant administration and minimally invasive surfactant treatment) as well as nebulization
\end{abstract}

karger@karger.com www.karger.com/neo

Karger $\stackrel{\text { ' }}{5}$

GOPEN ACCESS
(C) 2021 The Author(s)

Published by S. Karger AG, Basel

This is an Open Access article licensed under the Creative Commons Attribution-NonCommercial-4.0 International License (CC BY-NC) (http://www.karger.com/Services/OpenAccessLicense), applicable to the online version of the article only. Usage and distribution for commercial purposes requires written permission. of surfactant, although the latter is not ready for clinical application yet. In addition, given their therapeutic delivery to the lungs and subsequent alveolar distribution, surfactant preparations represent an attractive vehicle for pulmonary deposition of drugs in preterm infants. Further improvement of SRT and expansion of the field of application of lung surfactant may hold additional benefits, especially in the treatment of the most immature preterm infants.

(c) 2021 The Author(s).

Published by S. Karger AG, Basel

\section{Introduction}

Research for more than 3 decades has convincingly established surfactant replacement therapy (SRT) as highly effective treatment for newborn infants with respiratory distress syndrome (RDS) [1]. The lung physiology dynamically changes after SRT, historically performed via endotracheal tube in mechanically ventilated infants, with rapid improvements in pulmonary gas exchange, reduced work of breathing, and decreased risk of interstitial pulmonary edema, pneumothorax and mortality. In concert with further advances in perinatal medicine (e.g., use of antenatal steroids and prenatal transport of women at 
risk of preterm delivery to tertiary level care centers), SRT has particularly improved the survival of the smallest babies with gestational ages between 22 and 28 weeks [2]. Correspondingly, SRT has changed the nature of RDSassociated long-term pulmonary morbidities such as bronchopulmonary dysplasia (BPD), while the incidence of BPD remains high, that is, up to $50 \%$ infants $<29$ weeks' gestation $[2,3]$. Current approaches to prevent the lifetime burden of BPD are limited by its multifactorial etiology and the biological heterogeneity of affected infants. Translational studies reveal inflammation, apoptosis, disturbed alveolarization, airway remodeling, and angiogenesis as underlying, potentially malleable mechanisms of BPD development. Most of these pathophysiological pathways are associated with exposure to and duration of invasive mechanical ventilation (IMV), even for a brief period of time, as required for the INtubation-SURfactant-Extubation (INSURE) approach $[4,5]$. To minimize the risk of ventilation-induced injury, the use of nasal continuous positive airway pressure (nCPAP) has become the favored strategy for early respiratory management of preterm infants [6-8]. Efficient nCPAP is key to maintain the functional residual capacity of the immature lung; to promote the endogenous surfactant production, which typically takes place on the second or third day of life; and to provide adequate and stable oxygen delivery to vital organs [9]. However, a high proportion of extremely preterm infants initially stabilized on nCPAP still require IMV within the first $72 \mathrm{~h}$ of life [6-8]. The notion that surfactant deficiency might be the crucial risk factor for CPAP failure has led researchers to investigate less invasive modes of surfactant administration to spontaneously breathing infants. Most extensively studied are thin catheter administration techniques, for example, less invasive surfactant administration (LISA) or minimally invasive surfactant treatment (MIST), which have been shown to be both feasible and effective in reducing need for IMV in several randomized controlled trials (RCT) $[10,11]$. While thin catheter techniques (referenced in this review as LISA) have gained popularity in neonatal intensive care units (NICUs) across the world, noninvasive surfactant nebulization techniques remain in the province of research. Recent studies on surfactant as a carrier of topical drugs, for example, anti-inflammatory compounds, hold promise for more specific therapeutic strategies of RDS and BPD based on individualized risk patterns of preterm infants. We will review the current evidence for the "miracles" of surfactant, their challenges, and future directions of research.

\section{Less Invasive Surfactant Administration}

\section{The Scientific Concept of LISA}

The physiological rationale of LISA, initially developed in Denmark in 1992 [12], is to allow appropriate timing of surfactant treatment [13] to spontaneously breathing infants with RDS without the need for intubation and ventilation $[14,15]$. Animal research and pilot clinical trials determined the theoretical advantages of LISA compared to standard SRT, specifically: (i) avoidance of lung injury induced by positive pressure ventilation $[16,17]$, (ii) reduction of intubation trauma by using small diameter catheters for bolus installation [18-20], (iii) preservation of physiological larynx and glottis function [21], and (iv) maintenance of spontaneous breathing with beneficial effects on progressive lung recruitment and aeration $[22,23]$, pendelluft phenomenon resolution [24], and cerebral oxygenation [25].

\section{Clinical Evidence for LISA Effectiveness}

There is compelling evidence from RCTs and metaanalyses that LISA compared to standard SRT or INSURE reduces the need for IMV, particularly in the first $72 \mathrm{~h}$ after birth [26-28]. Systematic reviews also suggest that LISA carries benefits for health-related outcomes, that is, reduction of $\mathrm{BPD}$, mortality [28], and the composite outcome of BPD or death $[27,29]$. Conflicting data exist on the reduction for intracerebral hemorrhage $[28,29]$. Of note, the inclusion criteria of studies and their methodological quality are subject to bias, requiring further evidence by RCTs [30, 31]. In line with this, the first adequately powered RCT to study the effect of surfactant administration to spontaneously breathing infants on the composite outcome of mortality or BPD (OPTI-MIST trial, $n=606$ infants) has recently finished recruitment [32].

\section{Safety of LISA}

In the hands of experienced users, LISA has proved to be a feasible, safe, and well-tolerated approach $[33,34]$. Beyond surfactant reflux and repeated attempts to insert the catheter into the trachea, adverse side effects such as gagging, bradycardia, desaturations, apnea and decreases in regional cerebral oxygenation may occur in 5-40\%. These events are most often related to direct laryngoscopy and usually manageable with a brief period of noninvasive positive pressure ventilation and slowing the rate of surfactant administration [35-37]. Improvements in catheter devices, video laryngoscopy, and avoiding the use of Magill forceps can further reduce the risk of proce- 
Table 1. LISA failure, open questions and future directions of research on LISA

\begin{tabular}{|c|c|c|}
\hline $\begin{array}{l}\text { Issue to be } \\
\text { addressed }\end{array}$ & What is known? (study [ref.]) & Future research (study [ref.]) \\
\hline LISA failure & $\begin{array}{l}\text { Risk factor for failure } \\
\quad \text { - GA }<28 \text { weeks, highest } \mathrm{FiO}_{2} \geq 0.5 \text {, absence of ACS, } \\
\text { surfactant dose }<200 \mathrm{mg} / \mathrm{kg} \text { body weight of poractant alfa, } \\
\text { CRP }>10 \mathrm{mg} / \mathrm{L}, \text { muscular fatigue, insufficient respiratory } \\
\text { drive, or cardiovascular instability [41] } \\
\text { Surfactant dosing } \\
\text { - Optimum dose yet to be defined }[10,11,43] \\
\text { Risk of inhomogeneous surfactant distribution } \\
\text { - Inconsistent results of animal experiments }[16,17,23] \\
\text { - Pilot clinical study in preterm infants with electrical } \\
\text { impedance tomography: homogeneous distribution of } \\
\text { surfactant after LISA }\end{array}$ & $\begin{array}{l}\text { Determination of patient subgroups who benefit } \\
\text { most from LISA } \\
\text { Head-to-head studies comparing different } \\
\text { surfactant doses for LISA } \\
\quad \text { - Ongoing trial: OPTI-SURF (dosing groups } \\
\quad 100-130 \mathrm{mg} / \mathrm{kg} \text { and } 170-200 \mathrm{mg} / \mathrm{kg} \text { ) [92] } \\
\text { Investigation of the role of inhomogeneous } \\
\text { surfactant distribution in LISA failure }\end{array}$ \\
\hline $\begin{array}{l}\text { Analgesia and } \\
\text { sedation }\end{array}$ & $\begin{array}{l}\text { Clinical practice } \\
\text { - High variability, observational studies: } 15-30 \% \text { of infants } \\
\text { receive analgesia/sedation }[20,39,42] \\
\text { Drugs } \\
\text { - Fentanyl }(0.5-1 \mu \mathrm{g} / \mathrm{kg} \text { slow bolus infusion), morphine, } \\
\text { ketamine, midazolam, thiopental, and propofol [39] } \\
\text { Patient comfort } \\
\text { - COMFORTneo scores } \downarrow \text { in neonates sedated, procedure less } \\
\text { difficult to perform }[40] \\
\text { Patient safety } \\
\text { - Increased risk for desaturations and need for PPV; no } \\
\text { international consensus on pretreatment }[5,8,40,42]\end{array}$ & $\begin{array}{l}\text { Studies with standardized protocols for } \\
\text { pharmacological and non-pharmacological } \\
\text { interventions including neurodevelopmental } \\
\text { follow-up } \\
\text { Ongoing trial: PROLISA - use of propofol vs. } \\
\text { placebo for LISA (RCT) [48] }\end{array}$ \\
\hline $\begin{array}{l}\text { LISA as part } \\
\text { of less invasive } \\
\text { care bundle }\end{array}$ & $\begin{array}{l}\text { Delayed cord clamping } \\
\text { - Improved cardiopulmonary adaptation, mortality risk } \downarrow \text {, } \\
\text { physiological } \mathrm{SaO}_{2} \text { levels in early transition redefined }[45,46] \\
\text { nCPAP } \\
\text { - No consensus on nCPAP levels, mostly } 5-9 \mathrm{~cm} \mathrm{H}_{2} \mathrm{O} \text {; use of } \\
\text { different nCPAP devices and HFNC [20] } \\
\text { Timing of LISA } \\
\text { - No recommendation of prophylactic SRT [55, 56] } \\
\text { Often quasi-prophylactic approach at GA }<28 \text { weeks [20,37] } \\
\text { CPAP-recruitment-LISA } \\
\text { - Lung recruitment maneuver before surfactant improved } \\
\text { effectiveness in INSURE approach [58] } \\
\text { Timing of caffeine } \\
\text { - Evidence for caffeine use in extremely preterm infants } \\
\text { beyond the indications of the CAP trial is low [40, 44, 47] } \\
\text { - Often early caffeine administration in the delivery room } \\
\text { [20] }\end{array}$ & $\begin{array}{l}\text { Standardized treatment thresholds for LISA } \\
\text { (consensus) } \\
\text { Ongoing trial: OPTTIMMAL study of predefined } \\
\text { PEEP levels (RCT) [49] } \\
\text { Investigations on prophylactic vs. selective SRT } \\
\text { including long-term pulmonary outcome } \\
\text { Planned trial starts recruitment in } 2021 \text { [57] } \\
\text { Investigation of the role of recruitment maneuver } \\
\text { in LISA } \\
\text { Ongoing trial: CaLI RCT: early caffeine, CPAP, } \\
\text { and LISA vs. caffeine and CPAP [50], endpoint: } \\
\text { Avoiding mechanical ventilation at } \\
72 \mathrm{~h} \text { after birth }\end{array}$ \\
\hline $\begin{array}{l}\text { Benefit for } \\
\text { moderate, late } \\
\text { preterm, and } \\
\text { term infants }\end{array}$ & $\begin{array}{l}\text { Challenges } \\
\text { - Infants are more vigorous with higher GA, risk of } \\
\text { underdosing surfactant }[33,42,43] \\
\text { - Compared with INSURE, benefits of LISA not yet } \\
\text { determined (given a low risk of BPD) [20] }\end{array}$ & $\begin{array}{l}\text { Definition of health-relevant endpoints for LISA } \\
\text { vs. INSURE in moderate preterm and risk term } \\
\text { newborns (ventilator-associated infections, lung } \\
\text { function, and neurodevelopment) }\end{array}$ \\
\hline
\end{tabular}

ACS, antenatal corticosteroids; BPD, bronchopulmonary dysplasia; CRP, C-reactive protein; $\mathrm{FiO}_{2}$, fraction of inspired oxygen; GA, gestational age; HFNC, high-flow nasal cannula; INSURE, intubate-surfactant-extubate mode of surfactant delivery; nCPAP, nasal continuous positive airway pressure; PPV, positive pressure ventilation; RCT, randomized controlled trial; $\mathrm{SaO}_{2}$, oxygen saturation; SRT, surfactant replacement therapy. 
dure-associated injuries $[19,20]$. Training (e.g., manikin simulation scenarios) ahead of clinical implementation of LISA in the NICU is important for success and patient safety [38]. NICU guidelines are essential as high-risk infants who would previously have been intubated are now being managed to support spontaneous breathing at a much earlier and more vulnerable stage than ever before [39-42]. To enhance acceptance among healthcare professionals, LISA should not be considered as a single strategy but rather as part of a "less intensive support bundle," including delayed cord clamping, nCPAP for initial stabilization (even with high PEEP levels of $\geq 8 \mathrm{~cm} \mathrm{H}_{2} 0$ ), and caffeine administration to promote respiratory drive in the first hours of life [43-45]. Evidence on the specific impact of each "bundle" component on LISA effectiveness is still limited [46-48].

Retrospective chart reviews suggest that LISA-treated infants benefit from having less exposure to discomforting procedures early in life (e.g., blood tests, chest X-rays, transfusions, and antibiotic treatments) [49]. In this context, it will be of great value to determine whether the primary LISA approach reduces the rate of multiple re-intubations and ventilation episodes, particularly in the most vulnerable infants. In a large observational study of the German Neonatal Network (GNN) including 7,533 preterm infants $\leq 28$ weeks of age, LISA was associated with decreased risk for short-term outcomes such as mortality, BPD, clinical sepsis, pneumonia, intracerebral hemorrhage grades II-IV, surgery for persistent ductus arteriosus, and retinopathy requiring treatment. The only potential adverse effect of LISA was a slight increase in focal intestinal perforation in a subset of infants born at 23-24 weeks [50]. Whether "protective" or earlier intubation of extremely preterm infants with significant abdominal distension on CPAP reduces focal intestinal perforation requires further investigation. With regard to long-term outcome, no statistically significant differences in somatic or neurodevelopmental outcomes at 2 years were found between the LISA intervention group in the AMV (Avoidance of Mechanical Ventilation) trial [10] and the control group that received CPAP, rescue intubation, and surfactant treatment if needed [51]. Follow-up of the NINSAPP (Nonintubated Surfactant Application) trial [11] also found no difference between LISA intervention and standard intubation infants at 2 years, apart from higher mental developmental index values for LISA in the subgroup of 25-26 weeks' gestation [52]. Unpublished GNN data support the contention that the spontaneous breathing concept facilitated by nCPAP and LISA is of advantage for lung function of preterm children at early school age.
Given the current evidence on effectiveness and safety of LISA, recent guidelines for SRT mention LISA as the preferred mode for surfactant delivery in preterm infants spontaneously breathing on CPAP $[53,54]$. Different catheters/devices for LISA have been purpose-built and evaluated [19]. However, beyond the urgent need for further data on long-term outcome on LISA, open questions remain (Table 1) $[46-48,55,56]$.

\section{Nebulization of Surfactant}

Constituting a truly noninvasive approach of surfactant administration, nebulization avoids any airway manipulation at all [57-60]. Moreover, data from animal models suggest improved distribution of surfactant and minor systemic and cerebral hemodynamic side effects $[61,62]$. Almost 60 years have passed since Robillard et al. [63] reported on direct aerosolization of synthetic dipalmitoyl-phosphatidylcholine into the incubators of 11 preterm infants with RDS. This very first noncontrolled study found decreasing signs of RDS in 8 of these infants. Although early subsequent studies did not show beneficial effects of dipalmitoyl-phosphatidylcholine aerosol in neonatal RDS and discouraged surfactant aerosolization $[64,65]$, later studies in animal and in vitro models helped to develop efficient aerosol devices and establish adequate pulmonary deposition [66-68], which reawakened interest along with stepwise implementation of CPAP and noninvasive ventilation in neonatal practice.

\section{Preclinical and Clinical Evidence for Aerosolized Surfactant}

Animal studies of aerosolized surfactant in rabbit, piglet, and lamb models of RDS have shown inconsistent results, ranging from little or no effect of surfactant nebulization to pulmonary responses, similar to the effects of intratracheally administered surfactant $[62,63,66,67]$. Clinical data are still scarce. In total, 3 pilot studies [58, 60,69 ], a phase 1 clinical study [59] and a subsequent phase 2 clinical trial [70], and 4 RCTs have been published, comprising an overall number of 909 preterm infants (Table 2) [57, 59, 71, 72]. While all studies documented feasibility and safety, inconsistent results were found concerning efficacy. Improved oxygenation and superiority to nCPAP alone was found in only one [73] of the early studies. On the contrary, a first blinded RCT in 64 infants $>29$ weeks' gestation reported that treatment with nCPAP and nebulized surfactant reduced the requirement for intubation within $72 \mathrm{~h}$ from 69 to $34 \%$ 


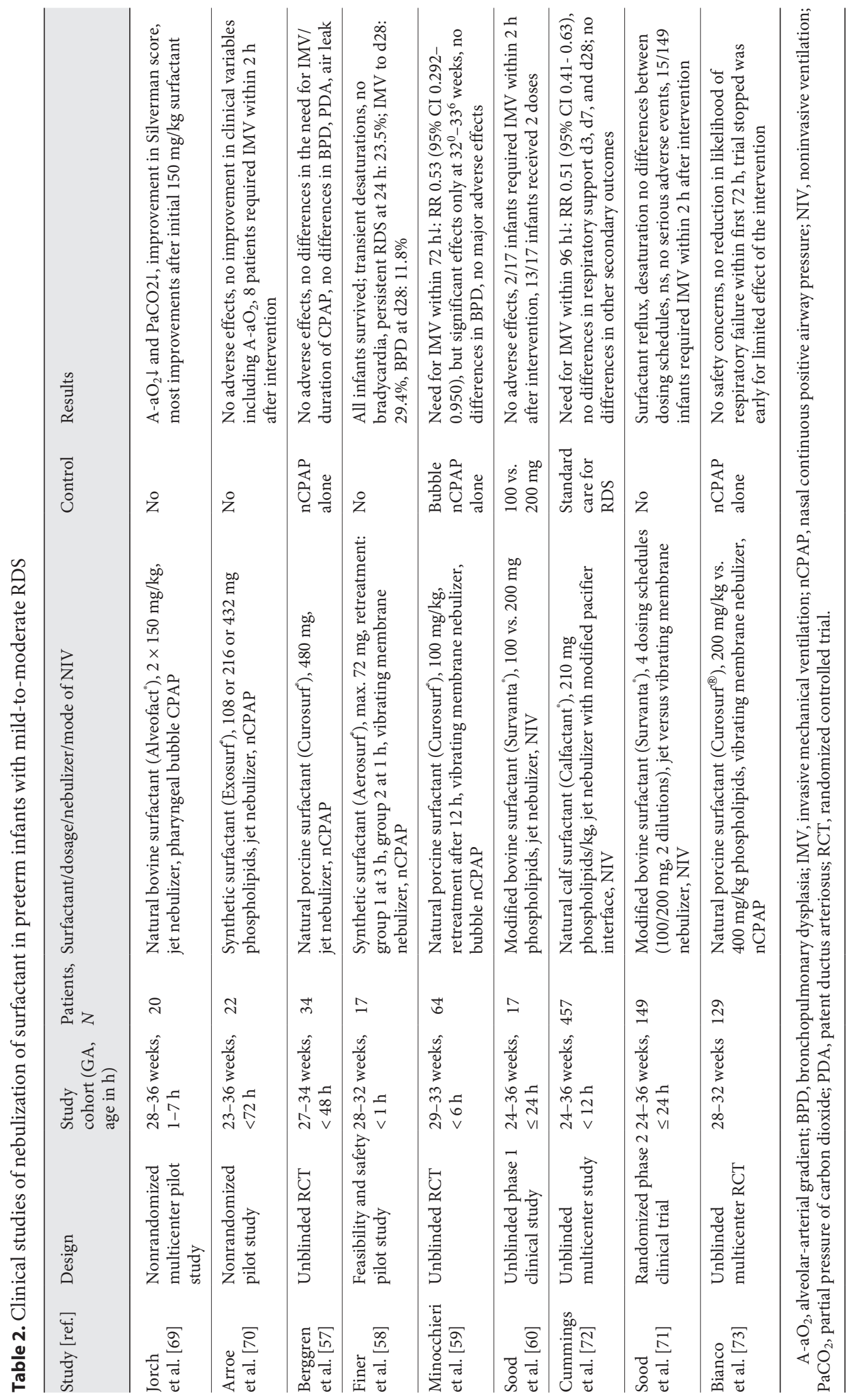


compared to nCPAP alone [59]. Recently, Cummings et al. [71] published the largest RCT to date, comparing nebulization to intubation and subsequent surfactant in 457 neonates with RDS. This multicenter trial confirmed feasibility and safety of the intervention in infants on CPAP, high-flow nasal cannula, and noninvasive ventilation using a modified nebulizer with pacifier interface [71]. A reduction in need for intubation and intratracheal surfactant from about $50 \%$ to about $25 \%$ was reported, with a number needed to treat of 5 [71]. However, lack of blinding and missing definitions of treatment failure implicated a high risk of bias [74]. Of note, in both RCTs, benefit of nebulization was limited to moderately preterm infants born beyond 31 weeks' gestation $[59,71]$. A phase 2 clinical trial including 149 preterm infants with RDS recently reported feasibility of 4 dosing schedules of aerosolized surfactant, absence of serious adverse events, and reduced need for intubation within $72 \mathrm{~h}$ [70]. Given that aerosol groups were compared to historical controls, however, conclusion about efficacy is limited [70]. Very recently, a multicenter RCT in 129 infants with mild-to-moderate RDS compared nCPAP with 2 different dosing regimens of nebulized surfactant with nCPAP alone [72]. The authors found no reduction in the likelihood of respiratory failure within the first $72 \mathrm{~h}$ of life, and the trial was stopped early due to limited effect of the intervention [72]. It is of interest that the same study group had demonstrated efficacy of aerosolized surfactant in preclinical settings before [68].

Factors Determining Pulmonary Delivery and Efficacy

Difficulties in pulmonary deposition and distribution of aerosolized surfactant arise from particle size, dose, and stability of formulation during nebulization, nebulizer-dependent recovery rates, and loss of surfactant to the device, oropharynx, esophagus, and exhaled air [75]. Different types of nebulizers have been tested [70,75]. While jet nebulizers often result in pulmonary deposition of $<1-$ $5 \%$ of aerosols, evolution of vibrating membrane nebulizers has improved aerosolization with deposition rates of $\geq 20 \%$ reported in animal and in vitro models, and pulmonary responses potentially similar to intratracheal surfactant in terms of oxygenation and lung mechanics $[67,68]$.

\section{Aerosolization of Synthetic Surfactant Preparations}

Few synthetic surfactants have been subject to nebulization in animal and in vitro models $[76,77]$. Synthetic formulations differ from natural surfactants with standardized and potentially optimized composition, production of higher quantities, and increased resistance against inactivation [78]. The feasibility of nebulization of synthetic surfactant has been confirmed in rabbit and lamb models of RDS [76, 77]. However, intervention was not superior to nCPAP, most likely due to limited pulmonary aerosol delivery [76]. Subsequent studies of highconcentration powder aerosolization aim to generate concentrated surfactant aerosols [77, 79]. Aerosolized synthetic surfactants have not been subjected to clinical trials apart from 2 pilot studies conducted 10 and more than 20 years ago, respectively, testing a peptide- and a non-peptide-containing synthetic surfactant in 39 infants in total $[58,69]$. Although the administration was shown to be feasible and safe, due to lack of control groups, conclusions regarding the efficacy cannot be drawn.

\section{Surfactant as a Vehicle for Topical Drugs}

Thirty years ago, animal experimental data showed for the first time that pulmonary surfactant, due to the unique spreading properties, could act as a vehicle for intratracheal delivery of the topical drug pentamidine [80]. Subsequent in vitro experiments and animal studies provided further evidence for a tentative role of pulmonary surfactant as carrier for antimicrobial agents with the aim of treating mainly adult patients with severe pneumonia [81, 82]; however, this fascinating idea has not been pursued in humans.

In the mid-1990s, it became evident that in a considerable number of very immature preterm infants, RDS was not only caused by a primary surfactant deficiency but also complicated by a complex and multifactorial pathogenesis of an injurious inflammatory sequence in the airways and lung tissue with the consequent increased risk of BPD [83, 84]. Fetal exposure to chorioamnionitis has been convincingly shown to initiate an inflammatory reaction in the immature lung, which can be aggravated by postnatal insults such as traumatic stabilization techniques, oxygen toxicity, initiation of mechanical ventilation, pulmonary and systemic infections, and others factors $[85,86]$. Systemic corticosteroids downregulated airway and tissue inflammation and improved pulmonary outcome $[87,88]$; however, with early postnatal steroids, the rate of adverse neurodevelopmental outcome is increased, and this strategy is no longer indicated [88].

\section{Clinical Evidence for a Potential Role of Pulmonary}

Surfactant as a Carrier of Topical Drugs

Use of natural surfactant as a vehicle for the topical anti-inflammatory drug budesonide in preterm infants 
with RDS was first reported by Yeh et al. [89]. The combination of early postnatal intratracheal instillation of budesonide and surfactant improved the combined outcome of death and BPD in a small pilot trial [88] and similarly pulmonary long-term outcome without causing adverse effects [90]. In a subsequent RCT in 3 centers that included 265 VLBW infants with severe RDS, intratracheal administration of budesonide with surfactant significantly decreased the incidence of BPD or death compared with surfactant alone (42 vs. $66 \%, p<0.001$ ) [91]. After the intervention, concentrations of pro-inflammatory cytokines in tracheal aspirate fluid were much lower in the budesonide/surfactant group.

Since this study included only infants with severe RDS, there are several open questions that need to be addressed in futuretrials: how does the administration ofbudesonide/ surfactant affect pulmonary and long-term outcome of very immature infants with mild RDS and those preterm infants with fetal exposure to chorioamnionitis? Will the surfactant administration technique such as less invasive strategies, the timing and duration of surfactant instillation or the dose of exogenous surfactant, for example, OPTI-SURF study [92], interfere with the anti-inflammatory effects of budesonide? Most importantly, these results need to be confirmed in a large, properly powered RCT. The results of the OPTIMIST trial are eagerly awaited and will be presented within the year 2021 [32].

A recently published observational cohort comparison reported that budesonide/surfactant did not change the overall incidence of BPD or death but reduced the severity of BPD and facilitated an earlier extubation [93]. Similarly, in a small dose-escalating trial of budesonide with surfactant, respiratory outcome of extremely low gestational age infants did not differ from historical controls. Interestingly, budesonide was detected in the blood of all infants with a half-life of $3.44 \mathrm{~h}$, and tracheal aspirate fluid cytokine levels decreased in those babies with elevated concentrations prior to treatment [94].

\section{Biophysical and Chemical Stability}

Biophysical and chemical stability of surfactant/ budesonide has been evaluated in a number of experimental studies confirming pulmonary and systemic antiinflammatory effects of this strategy in adult rabbits [95], mechanically ventilated preterm lambs [96], and rats [97]. In preterm neonatal rabbits, the combined administration attenuated hyperoxia-induced lung injury [98]. Moreover, pulmonary distribution of 2 natural surfactant preparations was recently tested, and both were shown to be effective vehicles for budesonide delivery [99].

\section{Conclusions and Future Directions}

LISA has become the preferred mode of surfactant delivery in preterm infants spontaneously breathing on CPAP, provided that neonatologists are experienced with this technique. Beyond the urgent need for further data on long-term outcome of LISA, there are open questions that should guide future research, in particular: (i) what are the predictive markers of "LISA failure"?, (ii) how to achieve a balance between patient comfort and support of spontaneous breathing, (iii) is there a comeback for prophylactic surfactant with LISA in the delivery room?, (iv) when to start caffeine, and (v) will late preterm infants or term infants benefit from LISA? With efficacy yet to be convincingly demonstrated, up to now nebulization is not ready for clinical use. Larger, adequately powered and well-designed trials are needed, in particular in very immature preterm infants at highest risk of lung injury. Issues to be addressed include the optimum dose and formulation of surfactant and technique of nebulization, positioning of devices in the ventilation circuit, optimum time of administration, lung recruitment strategies, and redosing. Current data indicate that addition of budesonide does not alter pulmonary distribution of surfactant, underlining the potential role of exogenous surfactant as an effective vehicle for targeted delivery of topical drugs, such as budesonide. In this context, new generation synthetic surfactants may represent an attractive substitute to natural surfactants in the future, with their composition being potentially optimized for homogeneous drug deposition.

\section{Acknowledgement}

We thank Carola Wolpert for carefully editing the manuscript.

\section{Conflict of Interest Statement}

C.H. has received honoraria for presentations and travel support from Chiesi Farmaceutici, a surfactant producer. C.H. served as advisor for Draeger Medical, a company producing incubators, monitors, and ventilators. C.P.S. has a consultancy agreement with Chiesi Farmaceutici S.p.A. (Parma, Italy). Both University Hospitals in Würzburg and Leipzig are participants in the German Neonatal Network. 


\section{Funding Sources}

C.H. received funding from the German Research Foundation (DFG-HA 6409-5/1; Immunoregulation of the Newborn Study).

\section{Author Contributions}

C.H., K.G., and C.P.S. equally contributed to the manuscript, being responsible for conception, design, drafting, and writing of this manuscript.

\section{References}

1 Rojas-Reyes MX, Morley CJ, Soll R. Prophylactic versus selective use of surfactant in preventing morbidity and mortality in preterm infants. Cochrane Database Syst Rev. 2012(3): CD000510.

2 Humberg A, Härtel C, Rausch TK, Stichtenoth $\mathrm{G}$, Jung $\mathrm{P}$, Wieg $\mathrm{C}$, et al. Active perinatal care of preterm infants in the German Neonatal Network. Arch Dis Child Fetal Neonatal Ed. 2020;105(2):190-5.

3 Stoll BJ, Hansen NI, Bell EF, Walsh MC, Carlo WA, Shankaran S, et al. Trends in care practices, morbidity, and mortality of extremely preterm neonates, 1993-2012. JAMA. 2015;314(10):1039-51.

4 Hillman NH, Moss TJ, Kallapur SG, Bachurski C, Pillow JJ, Polglase GR, et al. Brief, large tidal volume ventilation initiates lung injury and a systemic response in fetal sheep. Am J Respir Crit Care Med. 2007;176(6):575-81.

5 Sandri F, Plavka R, Ancora G, Simeoni U, Stranak Z, Martinelli S, et al. Prophylactic or early selective surfactant combined with nCPAP in very preterm infants. Pediatrics. 2010; 125(6):e1402-9.

6 Morley CJ, Davis PG, Doyle LW, Brion LP, Hascoet JM, Carlin JB, et al. Nasal CPAP or intubation at birth for very preterm infants. $\mathrm{N}$ Engl J Med. 2008;358(7):700-8.

7 Finer NN, Finer NN, Carlo WA, Walsh MC, Rich W, Gantz MG, et al. Early CPAP versus surfactant in extremely preterm infants. $\mathrm{N}$ Engl J Med. 2010;362(21):1970-9.

8 Dunn MS, Kaempf J, de Klerk A, de Klerk R, Reilly M, Howard D, et al. Randomized trial comparing 3 approaches to the initial respiratory management of preterm neonates. Pediatrics. 2011;128(5):e1069-76.

9 Zhong J, Lui K, Schindler T. The effect of continuous positive airway pressure on cerebral and splanchnic oxygenation in preterm infants. Neonatology. 2019;116(4):363-8.

10 Göpel W, Kribs A, Ziegler A, Laux R, Hoehn $\mathrm{T}$, Wieg C, et al. Avoidance of mechanical ventilation by surfactant treatment of spontaneously breathing preterm infants (AMV): an open-label, randomised, controlled trial. Lancet. 2011;378(9803):1627-34.

11 Kribs A, Roll C, Göpel W, Wieg C, Groneck $\mathrm{P}$, Laux R, et al. Nonintubated surfactant application vs conventional therapy in extremely preterm infants: a randomized clinical trial. JAMA Pediatr. 2015;169(8):723-30.

12 Verder H, Agertoft L, Albertsen P, Christensen NC, Curstedt T, Ebbesen F, et al. [Surfactant treatment of newborn infants with respiratory distress syndrome primarily treated with nasal continuous positive air pressure. A pilot study]. Ugeskr Laeg. 1992;154(31): 2136-9.

13 Bahadue FL, Soll R. Early versus delayed selective surfactant treatment for neonatal respiratory distress syndrome. Cochrane Database Syst Rev. 2012;11:CD001456.

14 Dargaville PA. CPAP, surfactant, or both for the preterm infant: resolving the dilemma. JAMA Pediatr. 2015;169(8):715-7.

15 Banerjee S, Fernandez R, Fox GF, Goss KCW, Mactier H, Reynolds P, et al. Surfactant replacement therapy for respiratory distress syndrome in preterm infants: United Kingdom national consensus. Pediatr Res. 2019; 86(1):12-4.

16 Niemarkt HJ, Kuypers E, Jellema R, Ophelders D, Hütten M, Nikiforou M, et al. Effects of less-invasive surfactant administration on oxygenation, pulmonary surfactant distribution, and lung compliance in spontaneously breathing preterm lambs. Pediatr Res. 2014; 76(2):166-70.

17 Ricci F, Bresesti I, LaVerde PAM, Salomone F, Casiraghi C, Mersanne A, et al. Surfactant lung delivery with LISA and InSurE in adult rabbits with respiratory distress. Pediatr Res. 2021 Jan 15. [Online ahead of print].

18 Barkhuff WD, Soll RF. Novel surfactant administration techniques: will they change outcome? Neonatology. 2019;115(4):411-22.

19 Vento M, Bohlin K, Herting E, Roehr CC, Dargaville PA. Surfactant administration via thin catheter: a practical guide. Neonatology. 2019;116(3):211-26.

20 Herting E, Härtel C, Göpel W. Less invasive surfactant administration: best practices and unanswered questions. Curr Opin Pediatr. 2020;32(2):228-34.

21 Crawshaw JR, Kitchen MJ, Binder-Heschl C, Thio M, Wallace MJ, Kerr LT, et al. Laryngeal closure impedes non-invasive ventilation at birth. Arch Dis Child Fetal Neonatal Ed. 2018; 103(2):F112-9.

22 Bohlin K, Bouhafs RK, Jarstrand C, Curstedt T, Blennow M, Robertson B. Spontaneous breathing or mechanical ventilation alters lung compliance and tissue association of exogenous surfactant in preterm newborn rabbits. Pediatr Res. 2005;57(5 Pt 1):624-30.

23 van der Burg PS, de Jongh FH, Miedema M, Frerichs I, van Kaam AH. Effect of minimally invasive surfactant therapy on lung volume and ventilation in preterm infants. J Pediatr. 2016;170:67-72.

24 Goncalves-Ferri WA, Rossi FS, Costa ELV, Correa L, Iope D, Pacce PD, et al. Lung re- cruitment and pendelluft resolution after less invasive surfactant administration in a preterm infant. Am J Respir Crit Care Med. 2020; 202:766-9.

25 Rey-Santano C, Mielgo VE, Gomez-Solaetxe MA, Salomone F, Gastiasoro E, Loureiro B. Cerebral oxygenation associated with INSURE versus LISA procedures in surfactantdeficient newborn piglet RDS model. Pediatr Pulmonol. 2019;54(5):644-54.

26 Rigo V, Lefebvre C, Broux I. Surfactant instillation in spontaneously breathing preterm infants: a systematic review and meta-analysis. Eur J Pediatr. 2016;175(12):1933-42.

27 Aldana-Aguirre JC, Pinto M, Featherstone RM, Kumar M. Less invasive surfactant administration versus intubation for surfactant delivery in preterm infants with respiratory distress syndrome: a systematic review and meta-analysis. Arch Dis Child Fetal Neonatal Ed. 2017;102(1):F17-23.

28 Bellos I, Fitrou G, Panza R, Pandita A. Comparative efficacy of methods for surfactant administration: a network meta-analysis. Arch Dis Child Fetal Neonatal Ed. 2021 Jan 15. [Online ahead of print].

29 Isayama T, Iwami H, McDonald S, Beyene J. Association of noninvasive ventilation strategies with mortality and bronchopulmonary dysplasia among preterm infants: a systematic review and meta-analysis. JAMA. 2016; 316(6):611-24.

30 Glaser K, Speer CP, Wright CJ. Fine tuning non-invasive respiratory support to prevent lung injury in the extremely premature infant. Front Pediatr. 2019;7:544.

31 Herting E, Härtel C, Göpel W. Less invasive surfactant administration (LISA): chances and limitations. Arch Dis Child Fetal Neonatal Ed. 2019;104(6):F655-9.

32 Dargaville PA, Kamlin CO, De Paoli AG, Carlin JB, Orsini F, Soll RF, et al. The OPTIMIST-A trial: evaluation of minimally-invasive surfactant therapy in preterm infants 25 28 weeks gestation. BMC Pediatr. 2014;14: 213.

33 Dargaville PA, Aiyappan A, Cornelius A, Williams C, De Paoli AG. Preliminary evaluation of a new technique of minimally invasive surfactant therapy. Arch Dis Child Fetal Neonatal Ed. 2011;96(4):F243-8.

34 Dargaville PA, Aiyappan A, De Paoli AG, Kuschel CA, Kamlin CO, Carlin JB, et al. Minimally-invasive surfactant therapy in preterm infants on continuous positive airway pressure. Arch Dis Child Fetal Neonatal Ed. 2013; 98(2):F122-6. 
35 Bertini G, Coviello C, Gozzini E, Bianconi T, Bresci C, Leonardi V, et al. Change of cerebral oxygenation during surfactant treatment in preterm infants: "LISA" versus "InSurE" procedures. Neuropediatrics. 2017;48(2):98-103.

36 Hanke K, Rausch TK, Paul P, Hellwig I, Krämer C, Stichtenoth G, et al. The effect of less invasive surfactant administration on cerebral oxygenation in preterm infants. Acta Paediatr. 2020;109(2):291-9.

37 Ambulkar H, Williams EE, Hickey A, Bhat R, Dassios T, Greenough A. Respiratory monitoring during less invasive surfactant administration in the delivery suite. Early Human Development. 2021;154:105311.

38 Rigo V, Debauche C, Maton P, Broux I, Van Laere D. Rigid catheters reduced duration of less invasive surfactant therapy procedures in manikins. Acta Paediatr. 2017;106(7):1091-6.

39 Mehler K, Oberthuer A, Haertel C, Herting E, Roth B, Goepel W, et al. Use of analgesic and sedative drugs in VLBW infants in German NICUs from 2003-2010. Eur J Pediatr. 2013; 172(12):1633-9.

40 Dekker J, Lopriore E, Rijken M, Rijntjes-Jacobs E, Smits-Wintjens V, Te Pas A. Sedation during minimal invasive surfactant therapy in preterm infants. Neonatology. 2016;109(4):308-13.

41 Janssen LC, Van Der Spil J, van Kaam AH, Dieleman JP, Andriessen P, Onland W, et al. Minimally invasive surfactant therapy failure: risk factors and outcome. Arch Dis Child Fetal Neonatal Ed. 2019;104(6):F636-42.

42 Krolak-Olejnik B, Hozejowski R, Szczapa T. Dose effect of poractant alfa in neonatal RDS: analysis of combined data from three prospective studies. Front Pediatr. 2020;8: 603716.

43 Schmidt B, Roberts RS, Davis P, Doyle LW, Barrington KJ, Ohlsson A, et al. Caffeine therapy for apnea of prematurity. N Engl J Med. 2006;354(20):2112-21.

44 Smit M, Dawson JA, Ganzeboom A, Hooper $\mathrm{SB}$, van Roosmalen J, te Pas AB. Pulse oximetry in newborns with delayed cord clamping and immediate skin-to-skin contact. Arch Dis Child Fetal Neonatal Ed. 2014;99(4):F309-14.

45 Fogarty M, Osborn DA, Askie L, Seidler AL, Hunter K, Lui K, et al. Delayed vs early umbilical cord clamping for preterm infants: a systematic review and meta-analysis. Am J Obstet Gynecol. 2018;218(1):1-18.

46 Chevallier M, Durrmeyer X, Ego A, Debillon T; PROLISA Study Group. Propofol versus placebo (with rescue with ketamine) before less invasive surfactant administration: study protocol for a multicenter, double-blind, placebo controlled trial (PROLISA). BMC Pediatr. 2020;20(1):199.

47 Waitz M, Engel C, Schloesser R, Rochwalsky U, Meyer S, Larsen A, et al. Application of two different nasal CPAP levels for the treatment of respiratory distress syndrome in preterm infants-"The OPTTIMMAL-Trial"-Optimizing PEEP To The IMMAture Lungs: study protocol of a randomized controlled trial. Trials. 2020;21(1):822.
48 Ines F, Hutson S, Coughlin K, Hopper A, Banerji A, Uy C, et al. Multicentre, randomised trial of preterm infants receiving caffeine and less invasive surfactant administration compared with caffeine and early continuous positive airway pressure (CaLI trial): study protocol. BMJ Open. 2021;11(1):e038343.

49 Bugter IAL, Janssen LCE, Dieleman J, Kramer BW, Andriessen P, Niemarkt HJ. Introduction of less invasive surfactant administration (LISA), impact on diagnostic and therapeutic procedures in early life: a historical cohort study. BMC Pediatr. 2020;20(1):421.

50 Härtel C, Paul P, Hanke K, Humberg A, Kribs A, Mehler K, et al. Less invasive surfactant administration and complications of preterm birth. Sci Rep. 2018;8(1):8333.

51 Herting E, Kribs A, Härtel C, von der Wense A, Weller U, Hoehn T, et al. Two-year outcome data suggest that less invasive surfactant administration (LISA) is safe. Results from the follow-up of the randomized controlled AMV (avoid mechanical ventilation) study. Eur J Pediatr. 2020;179(8):1309-13.

52 Mehler K, Broer A, Roll C, Göpel W, Wieg C, Jahn P, et al. Developmental outcome of extremely preterm infants is improved after less invasive surfactant application: developmental outcome after LISA. Acta Paediatr. 2021; 110(3):818-25.

53 Sweet DG, Carnielli V, Greisen G, Hallman M, Ozek E, Te Pas A, et al. European consensus guidelines on the management of respiratory distress syndrome -2019 update. Neonatology. 2019;115(4):432-50.

$54 \mathrm{Ng} \mathrm{EH}$, Shah V. Guidelines for surfactant replacement therapy in neonates. Paediatr Child Health. 2021;26(1):35-49.

55 Herting E, Härtel C, Kribs A, Göpel W. Less invasive surfactant administration: is surfactant prophylaxis coming back? [Abstract]. Neonatology.

56 Vento G, Ventura ML, Pastorino R, van Kaam $\mathrm{AH}$, Carnielli V, Cools F, et al. Lung recruitment before surfactant administration in extremely preterm neonates with respiratory distress syndrome (IN-REC-SUR-E): a randomised, unblinded, controlled trial. Lancet Respir Med. 2021;9(2):159-66.

57 Berggren E, Liljedahl M, Winbladh B, Andreasson B, Curstedt T, Robertson B, et al. Pilot study of nebulized surfactant therapy for neonatal respiratory distress syndrome. Acta Paediatr. 2000;89(4):460-4.

58 Finer NN, Merritt TA, Bernstein G, Job L, Mazela J, Segal R. An open label, pilot study of Aerosurf(R) combined with nCPAP to prevent RDS in preterm neonates. J Aerosol Med Pulm Drug Deliv. 2010;23:303-9.

59 Minocchieri S, Berry CA, Pillow JJ, CureNeb Study T. Nebulised surfactant to reduce severity of respiratory distress: a blinded, parallel, randomised controlled trial. Arch Dis Child Fetal Neonatal Ed. 2019;104(3):F313-9.

60 Sood BG, Cortez J, Kolli M, Sharma A, Delaney-Black V, Chen X. Aerosolized surfactant in neonatal respiratory distress syndrome:
Phase I study. Early human development. 2019;134:19-25.

61 Dijk PH, Heikamp A, Bambang Oetomo S. Surfactant nebulisation: lung function, surfactant distribution and pulmonary blood flow distribution in lung lavaged rabbits. Intensive Care Med. 1997;23(10):1070-6.

62 Rey-Santano C, Mielgo VE, Andres L, Ruizdel-Yerro E, Valls-i-Soler A, Murgia X. Acute and sustained effects of aerosolized vs. bolus surfactant therapy in premature lambs with respiratory distress syndrome. Pediatr Res. 2013;73(5):639-46.

63 Robillard E, Alarie Y, Dagenais-Perusse P, Baril E, Guilbeault A. Microaerosol administration of synthetic beta-gamma-dipalmitoylL-alpha-lecithin in the respiratory distress syndrome: a preliminary report. Can Med Assoc J. 1964;90:55-7.

64 Shannon D, Bunnell J. Dipalmitoyl lecithin aerosol in RDS. Pediatr Res. 1976;1:467.

65 Ivey H, Roth S, Kattwinkel J. Nebulization of sonicated phospholipids (PL) for treatment of respiratory distress syndrome (RDS) in infancy. Pediatr Res. 1977;12:573.

66 Milesi I, Tingay DG, Zannin E, Bianco F, Tagliabue P, Mosca F, et al. Intratracheal atomized surfactant provides similar outcomes as bolus surfactant in preterm lambs with respiratory distress syndrome. Pediatr Res. 2016; 80(1):92-100.

67 Nord A, Linner R, Milesi I, Zannin E, di Castri M, Bianco F, et al. A novel delivery system for supraglottic atomization allows increased lung deposition rates of pulmonary surfactant in newborn piglets. Pediatr Res. 2020;87(6): 1019-24.

68 Bianco F, Ricci F, Catozzi C, Murgia X, Schlun M, Bucholski A, et al. From bench to bedside: in vitro and in vivo evaluation of a neonatefocused nebulized surfactant delivery strategy. Respir Res. 2019;20(1):134.

69 Arroe M, Pedersen-Bjergaard L, Albertsen P, Bode S, Greison G, Jonsbo F. Inhalation of aerosolized surfactant exosurf to neonates treated with nasal continuous positive airway pressure. Prenat Neonatal Med. 1998;3:34652.

70 Sood BG, Thomas R, Delaney-Black V, Xin Y, Sharma A, Chen X. Aerosolized beractant in neonatal respiratory distress syndrome: a randomized fixed-dose parallel-arm phase II trial. Pulm Pharmacol Ther. 2021;66:101986.

71 Cummings JJ, Gerday E, Minton S, Katheria A, Albert G, Flores-Torres J, et al. Aerosolized calfactant for newborns with respiratory distress: a randomized t (5)rial. Pediatrics. 2020; 146(5):e20193967.

72 . Bianco F, Piccinno A, Fabbri L, Dani C. Surfactant aerosol delivery to spontaneously breathing preterm neonates: lesson learnt. [Abstract]. Neonatology.

73 Jorch G, Hartl H, Roth B, Kribs A, Gortner L, Schaible T, et al. Surfactant aerosol treatment of respiratory distress syndrome in spontaneously breathing premature infants. Pediatr Pulmonol. 1997;24(3):222-4. 
74 Glaser K, Wright CJ. Aerosolized calfactant in infants with RDS: surfactant replacement 2.0? Pediatrics. 2020;146(5):e2020021576.

75 Pillow JJ, Minocchieri S. Innovation in surfactant therapy II: surfactant administration by aerosolization. Neonatology. 2012;101(4): 337-44.

76 Walther FJ, Hernández-Juviel JM, Waring AJ. Aerosol delivery of synthetic lung surfactant. PeerJ. 2014;2:e403.

77 Walther FJ, Gupta M, Lipp MM, Chan H, Krzewick J, Gordon LM, et al. Aerosol delivery of dry powder synthetic lung surfactant to surfactant-deficient rabbits and preterm lambs on non-invasive respiratory support. Gates Open Res. 2019;3:6.

78 Curstedt T, Calkovska A, Johansson J. New generation synthetic surfactants. Neonatology. 2013;103(4):327-30.

79 Pohlmann G, Iwatschenko P, Koch W, Windt $\mathrm{H}$, Rast M, de Abreu MG, et al. A novel continuous powder aerosolizer (CPA) for inhalative administration of highly concentrated recombinant surfactant protein-C (rSP-C) surfactant to preterm neonates. J Aerosol Med Pulm Drug Deliv. 2013;26(6):370-9.

80 Kharasch VS, Sweeney TD, Fredberg J, Lehr J, Damokosh AI, Avery ME, et al. Pulmonary surfactant as a vehicle for intratracheal delivery of technetium sulfur colloid and pentamidine in hamster lungs. Am Rev Respir Dis. 1991;144(4):909-13.

81 van 't Veen A, Gommers D, Mouton JW, Kluytmans JA, Krijt EJ, Lachmann B. Exogenous pulmonary surfactant as a drug delivering agent: influence of antibiotics on surfactant activity. Br J Pharmacol. 1996;118(3): 593-8

82 Basabe-Burgos O, Zebialowicz J, Stichtenoth G, Curstedt T, Bergman P, Johansson J, et al. Natural derived surfactant preparation as a carrier of polymyxin E for treatment of Pseudomonas aeruginosa pneumonia in a nearterm rabbit model. J Aerosol Med Pulm Drug Deliv. 2019;32(2):110-8.
83 Groneck P, Götze-Speer B, Oppermann M, Eiffert H, Speer CP. Association of pulmonary inflammation and increased microvascular permeability during the development of bronchopulmonary dysplasia: a sequential analysis of inflammatory mediators in respiratory fluids of high-risk preterm neonates. Pediatrics. 1994;93(5):712-8.

84 Groneck P, Speer CP. Inflammatory mediators and bronchopulmonary dysplasia. Arch Dis Child Fetal Neonatal Ed. 1995;73(1):F1-

85 Schmidt B, Cao L, Mackensen-Haen S, Kendziorra H, Klingel K, Speer CP. Chorioamnionitis and inflammation of the fetal lung. Am J Obstet Gynecol. 2001;185(1):173-7.

86 Speer CP. Inflammation and bronchopulmonary dysplasia: a continuing story. Semin Fetal Neonatal Med. 2006;11(5):354-62.

87 Groneck P, Reuss D, Götze-Speer B, Speer CP. Effects of dexamethasone on chemotactic activity and inflammatory mediators in tracheobronchial aspirates of preterm infants at risk for chronic lung disease. J Pediatr. 1993; 122(6):938-44.

88 Doyle LW, Ehrenkranz RA, Halliday HL. Early ( $<8$ days) postnatal corticosteroids for preventing chronic lung disease in preterm infants. Cochrane Database Syst Rev. 2014: CD001146.

89 Yeh TF, Lin HC, Chang CH, Wu TS, Su BH, Li TC, et al. Early intratracheal instillation of budesonide using surfactant as a vehicle to prevent chronic lung disease in preterm infants: a pilot study. Pediatrics. 2008;121(5): e1310-8.

90 Kuo HT, Lin HC, Tsai CH, Chouc IC, Yeh TF. A follow-up study of preterm infants given budesonide using surfactant as a vehicle to prevent chronic lung disease in preterm infants. J Pediatr. 2010;156(4):537-41.

91 Yeh TF, Chen CM, Wu SY, Husan Z, Li TC Hsieh WS, et al. Intratracheal administration of budesonide/surfactant to prevent bronchopulmonary dysplasia. Am J Respir Crit Care Med. 2016;193(1):86-95.
92 Goss KCW, Gale C, Malone R, Longford N, Ratcliffe K, Modi N. Effect of surfactant dose on outcomes in preterm infants with respiratory distress syndrome: the OPTI-SURF study protocol. BMJ Open. 2020 Dec 12 10(12): e038959.

93 Kothe TB, Sadiq FH, Burleyson N, Williams HL, Anderson C, Hillman NH. Surfactant and budesonide for respiratory distress syndrome: an observational study. Pediatr Res. 2020;87(5):940-5.

94 McEvoy CT, Ballard PL, Ward RM, Rower JE Wadhawan R, Hudak ML, et al. Dose-escalation trial of budesonide in surfactant for prevention of bronchopulmonary dysplasia in extremely low gestational age high-risk newborns (SASSIE). Pediatr Res. 2020;88(4):62936.

95 Ricci F, Catozzi C, Ravanetti F, Murgia X, D'Aló F, Macchidani N, et al. In vitro and in vivo characterization of poractant alfa supplemented with budesonide for safe and effective intratracheal administration. Pediatr Res. 2017;82(6):1056-63.

96 Hillman NH, Kothe TB, Schmidt AF, Kemp MW, Royse E, Fee E, et al. Surfactant plus budesonide decreases lung and systemic responses to injurious ventilation in preterm sheep. Am J Physiol Lung Cell Mol Physiol. 2020;318(1):L41-8.

97 Baer B, McCaig L, Yamashita C, Veldhuizen R. Exogenous surfactant as a pulmonary delivery vehicle for budesonide in vivo. Lung. 2020;198(6):909-16.

98 Gie AG, Regin Y, Salaets T, Casiraghi C, Salomone F, Deprest J, et al. Intratracheal budesonide/surfactant attenuates hyperoxiainduced lung injury in preterm rabbits. Am J Physiol Lung Cell Mol Physiol. 2020;319(6): L949-56.

99 Chen $\mathrm{CM}$, Chang $\mathrm{CH}$, Chao $\mathrm{CH}$, Wang $\mathrm{MH}$, Yeh TF. Biophysical and chemical stability of surfactant/budesonide and the pulmonary distribution following intra-tracheal administration. Drug Deliv. 2019;26(1):604-11. 